Check for updates

Cite this: RSC Adv., 2020, 10, 40690

Received 12th September 2020 Accepted 22nd October 2020

DOI: $10.1039 / \mathrm{d} 0 \mathrm{ra0} 07824 \mathrm{~g}$

rsc.li/rsc-advances

\title{
Use of pyrazoles as ligands greatly enhances the catalytic activity of titanium iso-propoxide for the ring-opening polymerization of L-lactide: a cooperation effect $\dagger$
}

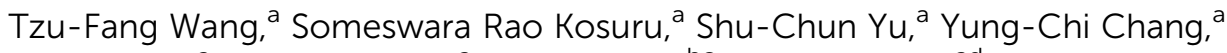 \\ Hsin-Yu Lai, ${ }^{a}$ Yu-Lun Chang, ${ }^{a}$ Kuo-Hui Wu, ${ }^{\text {bc }}$ Shangwu Ding ${ }^{\text {ad }}$ \\ and Hsuan-Ying Chen (D)*ade
}

Using $\mathrm{TiO}^{\mathrm{P}} \mathrm{Pr}_{4}$ with a pyrazole ligand for one-pot LA polymerization improved catalytic activity compared with using $\mathrm{TiO}^{\mathrm{P}} \mathrm{Pr}_{4}$ only. At $60{ }^{\circ} \mathrm{C}$, $\mathrm{TiO}^{\mathrm{P}} \mathrm{Pr}_{4}$ with ${ }^{\text {fur }} \mathrm{Pz}$ exhibited a higher catalytic activity (approximately 3fold) than $\mathrm{TiO}^{i} \mathrm{Pr}_{4}$. At room temperature, $\mathrm{TiO}^{\mathrm{i}} \mathrm{Pr}_{4}$ with ${ }^{\mathrm{Bu}} \mathrm{Pz}$ exhibited a higher catalytic activity (approximately 17-fold) than $\mathrm{TiO}^{\mathrm{P} P r_{4}}$. High molecular mass PLA $\left(M_{\mathrm{n}_{\mathrm{GPC}}}=51100\right.$, and $\left.\doteq=1.10\right)$ could be produced by using $\mathrm{TiO}^{\mathrm{i}} \mathrm{Pr}_{4}$ with ${ }^{\text {fur }} \mathrm{Pz}$ in melt polymerization $\left(\left[\mathrm{TiO}^{\mathrm{i}} \mathrm{Pr}_{4}\right]:\left[{ }^{\mathrm{fur}} \mathrm{Pz}\right]=1000: 1: 1\right.$ at $100{ }^{\circ} \mathrm{C}$, $240 \mathrm{~min}$ ). The crystal structure of ${ }^{\mathrm{Me}} \mathrm{Pz}_{2} \mathrm{Ti}_{2} \mathrm{O} \mathrm{Pr}_{7}$ revealed the cooperative activation between two $\mathrm{Ti}$ atoms during LA polymerization.

\section{Introduction}

Petrochemical plastics are extensively used in modern society; however, widely discarded plastic waste pollutes the environment continually ${ }^{1-4}$ because bacteria cannot decompose it naturally within a short period. To accelerate the environmental degradation of polymers, biodegradable polylactide (PLA) ${ }^{5-7}$ has been developed for creating a sustainable society. PLA-based biomaterials are used in various fields ${ }^{8-18}$ because of their biocompatible ${ }^{19,20}$ and permeable ${ }^{21}$ physical properties. One of the methods of PLA synthesis is the Lewis acidic metal-catalyzed ring-opening polymerization (ROP) of cyclic esters. ${ }^{22-31}$

For biomaterials, metal residuals present in resulting PLA are a serious problem, and using catalysts with non-cytotoxic metals is a straightforward approach to solving this problem. Because of the non-cytotoxic property and strong Lewis acidity of titanium, Ti

${ }^{a}$ Department of Medicinal and Applied Chemistry, Drug Development and Value Creation Research Center, Kaohsiung Medical University, Kaohsiung, Taiwan, 80708, Republic of China. E-mail: hchen@kmu.edu.tw; Fax: +886-7-3125339; Tel: +886-7-3121101 ext. 2585

${ }^{b}$ Department of Chemistry, Graduate School of Science, The University of Tokyo, Tokyo 113-0033, Japan

${ }^{c}$ Department of Chemistry, Tamkang University, Tamsui 251, Taiwan, Republic of China

${ }^{d}$ Department of Chemistry, National Sun Yat-sen University, Kaohsiung, Taiwan, 80424, Republic of China

${ }^{e}$ Department of Medical Research, Kaohsiung Medical University Hospital, Kaohsiung 80708, Taiwan, Republic of China

$\dagger$ Electronic supplementary information (ESI) available. CCDC 1568213. For ESI and crystallographic data in CIF or other electronic format see DOI: 10.1039/d0ra07824g complexes $^{22,23,30-33}$ are commonly used catalysts in LA ROP. Numerous Ti complexes bearing various ligands such as calix[4] arene, ${ }^{33,34}$ Schiff base, ${ }^{35-39}$ salen, ${ }^{40-42}$ salan, ${ }^{43-46}$ phenolate, ${ }^{47-50}$ aminophenolate, ${ }^{51,52}$ benzotriazole phenolate, ${ }^{53-55}$ phosphinophenolate, ${ }^{56}$ thiophenolate, ${ }^{57,58}$ bis-phenolate-N-heterocyclic carbene, ${ }^{45}$ pyridonate, ${ }^{59,60}$ and pyrrolide ${ }^{61}$ have been reported to exhibit considerable catalytic activity or controllability, which is contributed by ligands. However, for most studies, focusing on materials is inconvenient, because the synthesis and purification of $\mathrm{Ti}$ catalysts are time-consuming processes. An efficient method of fabricating PLA without time-consuming Ti catalyst-base synthesis and purification is necessary. Herein, commercially available $\mathrm{Ti}$ alkoxides was also used catalysts for cyclic esters polymerization. ${ }^{62-65}$ Recently, dinuclear Ti complexes ${ }^{38}$ bearing hydrazinebridging Schiff base ligands (Fig. 1) were reported to exhibit

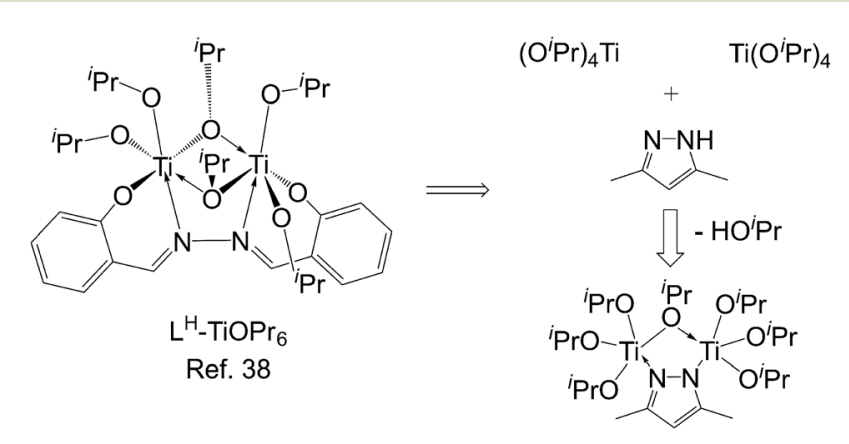

Fig. 1 Strategy of dinuclear $\mathrm{Ti}$ complexes in LA polymerization inspired by the literature. 


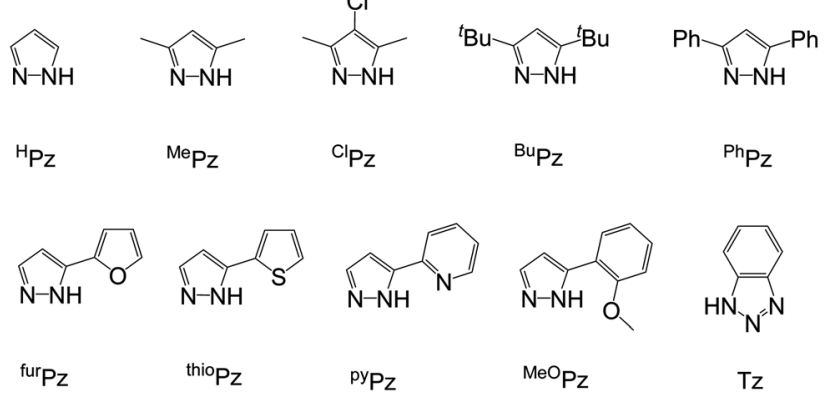

Fig. 2 Pyrazole derivatives used in this study.

a high catalytic activity of LA polymerization because of the cooperation between two Ti atoms. Based on this study, if pyrazole is added to LA polymerization with titanium iso-propoxide $\left(\mathrm{TiO}^{\mathrm{i}} \mathrm{Pr}_{4}\right)$ as a catalyst, bringing two Ti atoms close together to enable dinuclear cooperation is possible. Following this strategy, several pyrazole derivatives (Fig. 2) were added to LA polymerization with a $\mathrm{TiO}^{\mathrm{i}} \mathrm{Pr}_{4}$ catalyst to investigate dinuclear cooperation relative to the mixture of $\mathrm{TiO}^{\mathrm{i}} \mathrm{Pr}_{4}$ and pyrazole.

\section{Experimental section}

\subsection{Chemicals}

Standard Schlenk techniques and a $\mathrm{N}_{2}$-filled glovebox were used all over the isolation and treatment of all the compounds. Solvents, $\mathrm{L}^{-}$ lactide (LA), and deuterated solvents were purified prior to use. LA,
${ }^{\mathrm{H}} \mathrm{Pz},{ }^{\mathrm{Me}} \mathrm{Pz},{ }^{\mathrm{Bu}} \mathrm{Pz},{ }^{\mathrm{Ph}} \mathrm{Pz},{ }^{\text {fur }} \mathrm{Pz},{ }^{\text {thio }} \mathrm{Pz}, \mathrm{Tz},{ }^{\mathrm{py}} \mathrm{Pz}$, and ${ }^{\mathrm{M}}{ }^{\mathrm{Me}} \mathrm{Pz}$ were purchased from Aldrich. ${ }^{\mathrm{Cl}} \mathrm{PZ}^{66}$ were prepared following literature procedures. ${ }^{1} \mathrm{H}$ and ${ }^{13} \mathrm{C}$ NMR spectra were recorded on a Varian Gemini $2000-200\left(200 \mathrm{MHz}\right.$ for ${ }^{1} \mathrm{H}$ and $50 \mathrm{MHz}$ for ${ }^{13} \mathrm{C}$ ) spectrometer. Chemical shifts (in ppm) of ${ }^{1} \mathrm{H}$ NMR spectra were referenced to tetramethylsilane ( $\delta=0 \mathrm{ppm})$ in $\mathrm{CDCl}_{3}$ as an internal standard, and chemical shifts of ${ }^{13} \mathrm{C}$ NMR spectra were reported in ppm referenced to the center line of a triplet at $77.0 \mathrm{ppm}$ of $\mathrm{CDCl}_{3}$. Microanalyses were performed using a Heraeus CHN-O-RAPID instrument. The gel permeation chromatography (GPC) measurements were performed on a Jasco PU-2080 PLUS HPLC pump system equipped with a differential Jasco RI-2031 PLUS refractive index detector using THF (HPLC grade) as an eluent (flow rate $1.0 \mathrm{~mL} \mathrm{~min}^{-1}$, at $40^{\circ} \mathrm{C}$ ). The chromatographic column was JORDI Gel DVB $10^{-3} \AA$, and the calibration curve was made by primary polystyrene standards to calculate molar masses of PLA. Values of $M_{\mathrm{n}_{\mathrm{GPC}}}$ were obtained through gel permeation chromatography (GPC) times 0.58.

\subsection{Synthesis of ${ }^{\mathrm{Me}} \mathrm{Pz}_{2} \mathrm{Ti}_{2} \mathrm{O}^{\mathrm{i}} \mathrm{Pr}_{7}$}

A mixture of ${ }^{\mathrm{Me}} \mathrm{Pz}(0.96 \mathrm{~g}, 10 \mathrm{mmol})$ and $\mathrm{TiO}^{\mathrm{i}} \mathrm{Pr}_{4}(2.84 \mathrm{~g}, 10$ $\mathrm{mmol})$ in toluene $(20 \mathrm{~mL})$, was stirred at room temperature for $24 \mathrm{~h}$. Volatile materials were removed under vacuum to give light yellow mud, and then hexane was transferred to be the suspension. The light-yellow powder was obtained after filtering, and was recrystallized in toluene to form the crystal. Yield: $1.15 \mathrm{~g}(33 \%) .{ }^{1} \mathrm{H}$ NMR spectrum $\left(\mathrm{CDCl}_{3}, 200 \mathrm{MHz}\right.$, Fig. S1†) was complex, but it could be assigned that two $\beta$-Hs were at 5.59 and $5.43 \mathrm{ppm}$, and the methine protons of

Table 1 L-Lactide polymerization with the mixture of $\mathrm{TiO}^{i} \mathrm{Pr}_{4}$ and pyrazole derivatives as catalysts in toluene ${ }^{a}$

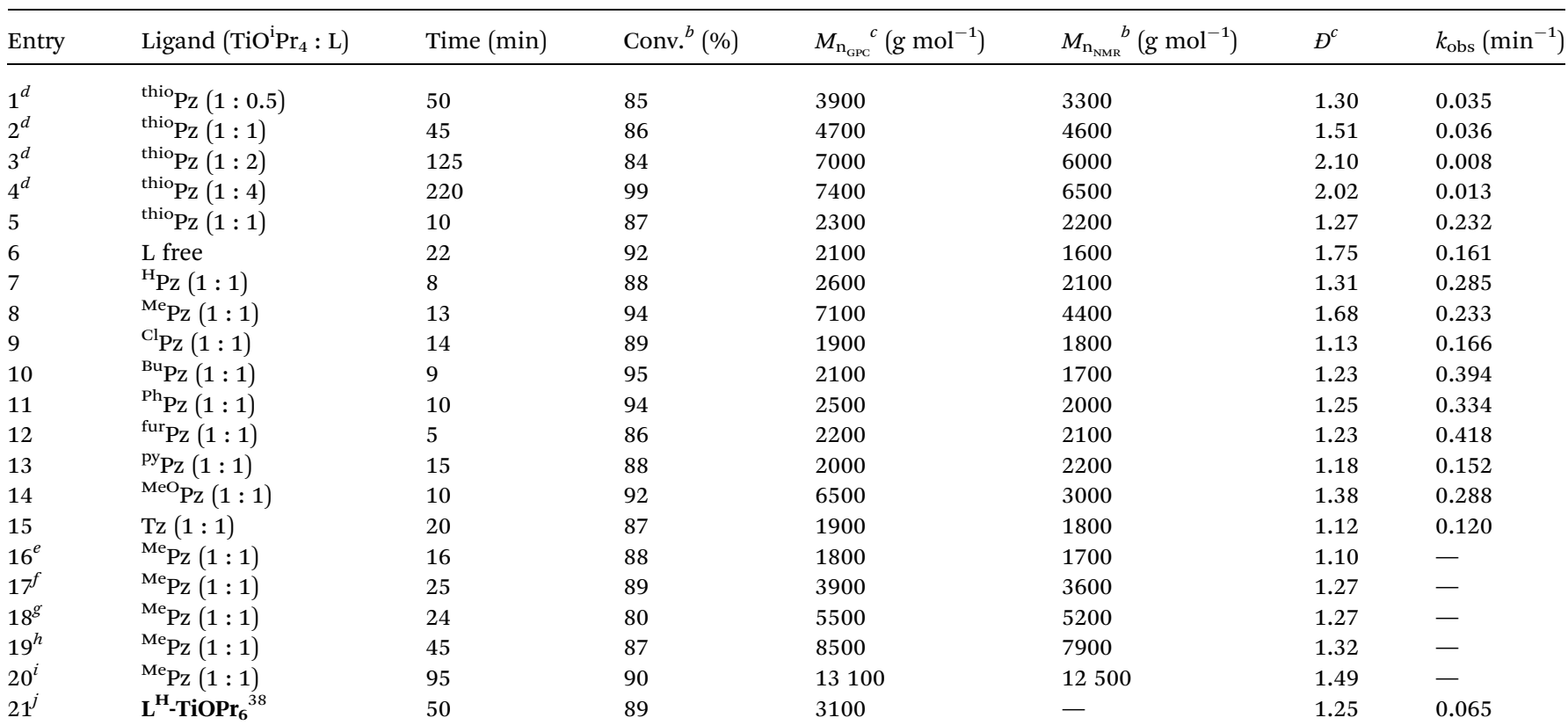

${ }^{a}$ In general, the reaction was carried out in $5 \mathrm{~mL}$ toluene with $[\mathrm{LA}]=2 \mathrm{M}$ at $60^{\circ} \mathrm{C}$ for LA polymerization $\left([\mathrm{LA}]:\left[\mathrm{TiO}^{\mathrm{i}} \mathrm{Pr}_{4}\right]=50: 1\right) .{ }^{b} \mathrm{The}$ data were determined using ${ }^{1} \mathrm{H}$ NMR analysis. ${ }^{c}$ Values of $M_{\mathrm{n}}$ were corrected considering Mark-Houwink factor (0.58) from polystyrene standards in THF. ${ }^{d}[\mathrm{LA}]=1 \mathrm{M}$, in $5 \mathrm{~mL}$ toluene, $[\mathrm{LA}]:\left[\mathrm{TiO}^{\mathrm{i}} \mathrm{Pr}_{4}\right] \stackrel{\mathrm{GPC}}{=} 100: 1 .^{e}[\mathrm{LA}]:\left[\mathrm{TiO}^{\mathrm{i}} \mathrm{Pr}_{4}\right]:\left[{ }^{\mathrm{Me}} \mathrm{Pz}\right]=50: 1: 1,\left[\mathrm{TiO}^{\mathrm{i}} \mathrm{Pr}_{4}\right]=13.4 \mathrm{mM}$ in toluene $15 \mathrm{~mL}$. $f[\mathrm{LA}]:\left[\mathrm{TiO}^{\mathrm{i}} \mathrm{Pr}_{4}\right]:\left[{ }^{\mathrm{Me}} \mathrm{Pz}\right]=100: 1: 1,\left[\mathrm{TiO}^{\mathrm{i}} \mathrm{Pr}_{4}\right]=13.4 \mathrm{mM}$ in toluene $15 \mathrm{~mL} \cdot{ }^{g}[\mathrm{LA}]:\left[\mathrm{TiO}^{\mathrm{i}} \mathrm{Pr}_{4}\right]:\left[{ }^{\mathrm{Me}} \mathrm{Pz}^{\mathrm{O}}\right]=150: 1: 1,\left[\mathrm{TiO}^{\mathrm{i}} \mathrm{Pr}_{4}\right]=13.4 \mathrm{mM}$ in toluene $15 \mathrm{~mL} .{ }^{h}[\mathrm{LA}]:\left[\mathrm{TiO}^{\mathrm{i}} \mathrm{Pr}_{4}\right]:\left[{ }^{\mathrm{Me}} \mathrm{Pz}\right]=200: 1: 1,\left[\mathrm{TiO}^{\mathrm{i}} \mathrm{Pr}_{4}\right]=13.4 \mathrm{mM}$ in toluene $15 \mathrm{~mL}{ }^{i}[\mathrm{LA}]:\left[\mathrm{TiO}^{\mathrm{i}} \mathrm{Pr}_{4}\right]:\left[{ }^{\mathrm{Me}} \mathrm{Pz}\right]=300: 1: 1,\left[\mathrm{TiO}^{\mathrm{i}} \mathrm{Pr}_{4}\right]=$ $13.4 \mathrm{mM}$ in toluene $15 \mathrm{~mL} \cdot{ }^{j}[\mathrm{LA}]:\left[\mathbf{L}^{\mathbf{H}}-\mathbf{T i O P r}_{6}\right]=100: 1,[\mathrm{LA}]=2.0 \mathrm{mM}$ in toluene $5 \mathrm{~mL}$ at $60{ }^{\circ} \mathrm{C}$. 


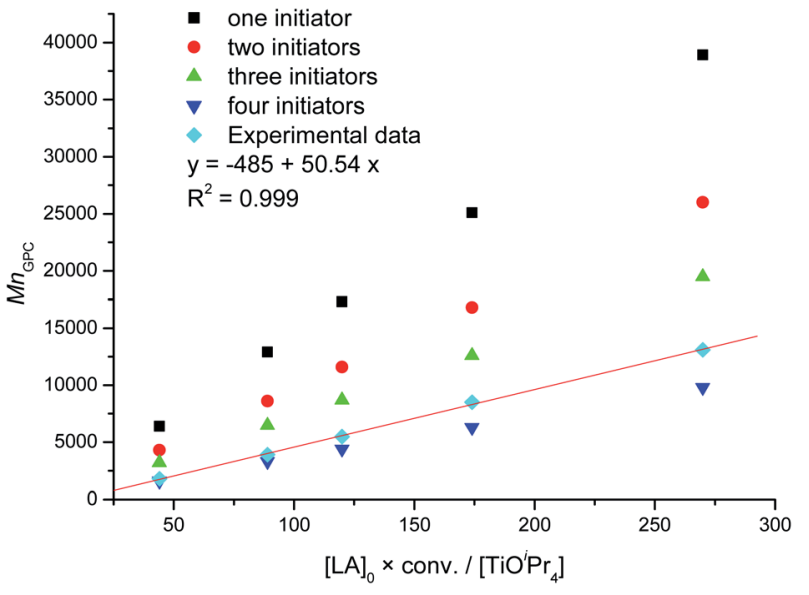

Fig. 3 Linear plot of various $M_{n_{\text {cal }}}$ with the supposed initiators and $M_{\mathrm{n}_{\mathrm{GPC}}}$ against [LA] $]_{0} \times$ conv./[TiO'Pr $\left.\mathrm{Tr}_{4}\right]$ (Table 1, entries 16-20).

isopropyl oxide were at 4.92-4.28 ppm, and dimethyl groups of ${ }^{\mathrm{Me}} \mathrm{Pz}$ were at 2.39 and $2.14 \mathrm{ppm}$.

\section{Results and discussion}

\subsection{Polymerization of LA}

Table 1 presents the conditions for optimizing LA polymerization by using a mixture of $\mathrm{TiO}^{\mathrm{i}} \mathrm{Pr}_{4}$ and ${ }^{\text {thio }} \mathrm{Pz}$ as the catalyst. Entries 1-5 in Table 1 reveal that the $1: 1$ ratio of $\operatorname{TiO}^{\mathrm{i}} \mathrm{Pr}_{4}$ and
${ }^{\text {thio }} \mathrm{Pz}\left([\mathrm{LA}]=1 \mathrm{M},\left[\mathrm{TiO}^{\mathrm{i}} \mathrm{Pr}_{4}\right]=10 \mathrm{mM}\right)$ exhibited the fastest polymerization rate. When [LA] was increased to $2 \mathrm{M}$ with $40 \mathrm{mM}$ of $\left[\mathrm{TiO}^{\mathrm{i}} \mathrm{Pr}_{4}\right]$, after $10 \mathrm{~min}$, the conversion became $87 \%$. Under this condition $\left([\mathrm{LA}]=2 \mathrm{M},[\mathrm{LA}]:\left[\mathrm{TiO}^{\mathrm{i}} \mathrm{Pr}_{4}\right]:\left[{ }^{\text {thio }} \mathrm{Pz}\right]=\right.$ $50: 1: 1$ in $5 \mathrm{~mL}$ toluene), various pyrazole derivatives were used to analyze LA polymerization, and all pyrazole derivatives improved the catalytic activity of $\mathrm{TiO}^{\mathrm{i}} \mathrm{Pr}_{4}$, except ${ }^{\mathrm{Py}} \mathrm{Pz}$ and $\mathrm{Tz}$ in the following order: ${ }^{\text {fur }} \mathrm{Pz}>{ }^{\mathrm{Bu}} \mathrm{Pz}>{ }^{\mathrm{Ph}} \mathrm{Pz}>{ }^{\mathrm{MeO}} \mathrm{Pz}>{ }^{\mathrm{H}} \mathrm{Pz}>{ }^{\mathrm{Me}} \mathrm{Pz}={ }^{\text {thio }} \mathrm{Pz}>$ ${ }^{\mathrm{Cl}} \mathrm{Pz}>{ }^{\mathrm{py}} \mathrm{Pz}>\mathrm{Tz}$. Although ${ }^{\mathrm{Me}} \mathrm{Pz}$ improved the catalytic activity of $\mathrm{TiO}^{\mathrm{i}} \mathrm{Pr}_{4}$, it provided low controllability (dispersity, $D=1.68$ ). To solve this problem, the $\mathrm{TiO}^{\mathrm{i}} \mathrm{Pr}_{4}$ concentration was decreased from 20 to $13.4 \mathrm{mM}$, and the $\oslash$ value was decreased to 1.10 . LA polymerization using $\mathrm{TiO}^{\mathrm{i}} \mathrm{Pr}_{4}(13.4 \mathrm{mM})$ as a catalyst with ${ }^{\mathrm{Me}} \mathrm{Pz}$ was systematically investigated with the $[\mathrm{LA}] /\left[\mathrm{TiO}^{\mathrm{i}} \mathrm{Pr}_{4}\right]$ ratio ranging from 50 to 300 (entries 16-20). The results revealed that LA polymerization was controllable, confirmed by the linear relationship between $[\mathrm{LA}]_{0} /\left[\mathrm{TiO}^{\mathrm{i}} \mathrm{Pr}_{4}\right]$ and $M_{\mathrm{n}_{\mathrm{GPC}}}$ (Fig. 3). However, the controllability in the $[\mathrm{LA}] /\left[\mathrm{TiO}^{\mathrm{i}} \mathrm{Pr}_{4}\right]$ ratio of $300(\nexists=1.49$, entry 20 in Table 1$)$ was low, and it may be ascribed to transesterification ${ }^{67}$ because of the long polymerization time at $60{ }^{\circ} \mathrm{C}$. Fig. 3 revealed that four isopropoxides of $\mathrm{TiO}^{\mathrm{i}} \mathrm{Pr}_{4}$ could be initiators to initiate $\mathrm{LA}$. $\mathrm{TiO}^{\mathrm{i}} \mathrm{Pr}_{4}$ with ${ }^{\text {thio }} \mathrm{Pz}$ exhibited a higher catalytic activity (3.5 folds) in LA polymerization than $\mathbf{L}^{\mathbf{H}}-\mathbf{T i O P r}_{\mathbf{6}}$ (entry 21) ${ }^{38}$ did.

A survey of LA ROP using Ti complexes as catalysts revealed that few Ti catalysts could polymerize LA at room temperature. Therefore, LA polymerization was conducted at room temperature (Table

Table 2 L-Lactide polymerization with the mixture of $\mathrm{TiO}^{\mathrm{i}} \mathrm{Pr}_{4}$ and pyrazole derivatives as catalysts in $\mathrm{CH}_{2} \mathrm{Cl}_{2}$ at room temperature

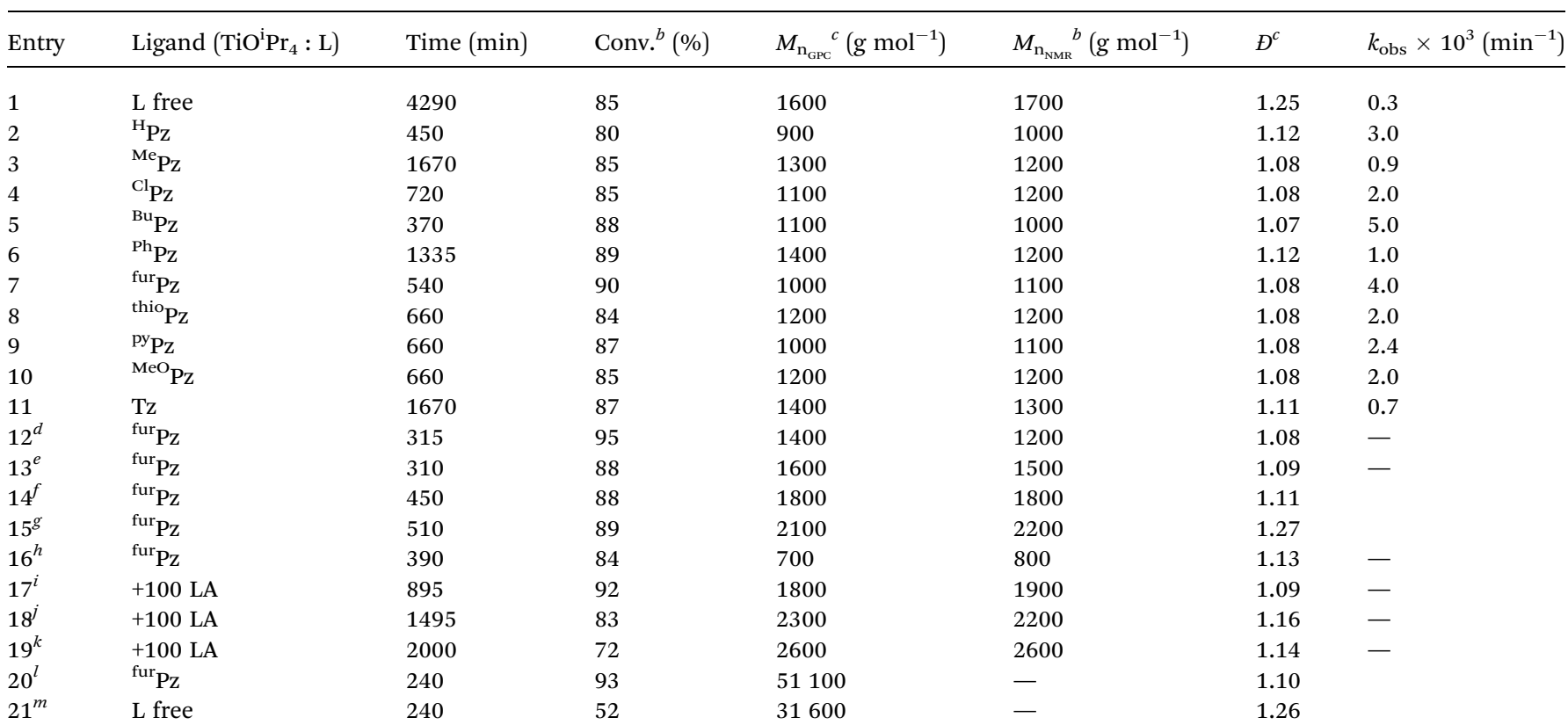

${ }^{a}$ In general, the reaction was carried out in $2.5 \mathrm{~mL} \mathrm{CH}_{2} \mathrm{Cl}_{2}$ with [LA] $=2 \mathrm{M}$ at room temperature for LA polymerization ([LA]: [TiO $\left.\left.{ }^{\mathrm{i}} \mathrm{Pr}_{4}\right]=25: 1\right)$. ${ }^{b}$ The data were determined using ${ }^{1} \mathrm{H}$ NMR analysis. ${ }^{c}$ Values of $M_{\mathrm{n}_{\mathrm{Be}}}$ were corrected considering Mark-Houwink factor $(0.58)$ from polystyrene standards in THF. ${ }^{d}[\mathrm{LA}]:\left[\mathrm{TiO}^{\mathrm{i}} \mathrm{Pr}_{4}\right]:\left[{ }^{\mathrm{fur}} \mathrm{Pz}\right]=37.5: 1: 1,\left[\mathrm{TiO}^{\mathrm{i}} \mathrm{Pr}_{4}\right] \stackrel{\mathrm{H}_{\mathrm{GPC}}}{=} 0.08 \mathrm{M}$ in $2.5 \mathrm{~mL} \mathrm{CH}_{2} \mathrm{Cl}_{2} \cdot{ }^{e}[\mathrm{LA}]:\left[\mathrm{TiO}^{\mathrm{i}} \mathrm{Pr}_{4}\right]:\left[{ }^{\mathrm{fur}} \mathrm{Pz}^{\mathrm{H}}\right]=43.75: 1: 1,\left[\mathrm{TiO}^{\mathrm{i}} \mathrm{Pr}_{4}\right]$ $=0.08 \mathrm{M}$ in $\left.2.5 \mathrm{~mL} \mathrm{CH} \mathrm{Cl}_{2} \cdot{ }^{f}[\mathrm{LA}]:\left[\mathrm{TiO}^{\mathrm{i}} \mathrm{Pr}_{4}\right]:{ }^{\mathrm{fur}} \mathrm{Pz}\right]=50: 1: 1,\left[\mathrm{TiO}^{\mathrm{i}} \mathrm{Pr}_{4}\right]=0.08 \mathrm{M}$ in $2.5 \mathrm{~mL} \mathrm{CH}_{2} \mathrm{Cl}_{2} .{ }^{g}[\mathrm{LA}]:\left[\mathrm{TiO}^{\mathrm{i}} \mathrm{Pr}_{4}\right]:\left[{ }^{\mathrm{fur}} \mathrm{Pz}\right]=62.5: 1: 1$, $\left[\mathrm{TiO}^{\mathrm{i}} \mathrm{Pr}_{4}\right]=0.08 \mathrm{M}$ in $2.5 \mathrm{~mL} \mathrm{CH} \mathrm{Cl}_{2} \cdot{ }^{h}[\mathrm{LA}]:\left[\mathrm{TiO}^{\mathrm{i}} \mathrm{Pr}_{4}\right]:\left[{ }^{\text {fur } \mathrm{Pz}}\right]=25: 1: 1,\left[\mathrm{TiO}^{\mathrm{i}} \mathrm{Pr}_{4}\right]=0.08 \mathrm{M}$ in $2.5 \mathrm{~mL} \mathrm{CDCl}_{3}{ }^{i}$ After the conversion of the reaction (entry 16) was $84 \%$, LA $(0.72 \mathrm{~g})$ was transferred into the solution. ${ }^{j}$ After the conversion of the reaction (entry 17$)$ was $92 \%$, LA (0.72 g) was transferred into the solution. ${ }^{k}$ After the conversion of the reaction (entry 17$)$ was $83 \%$, LA (0.72 g) was transferred into the solution. ${ }^{l}\left[\mathrm{TiO}^{\mathrm{i}} \mathrm{Pr}_{4}\right]:\left[{ }^{\text {fur }} \mathrm{Pz}\right]=1000: 1: 1$, melt reaction at $100{ }^{\circ} \mathrm{C} .{ }^{m}[\mathrm{LA}]:\left[\mathrm{TiO}^{\mathrm{i}} \mathrm{Pr}_{4}\right]=1000: 1$, melt reaction at $100{ }^{\circ} \mathrm{C}$. 
2) to determine whether the addition of pyrazole ligands can enhance the catalytic ability of $\mathrm{TiO}^{\mathrm{i}} \mathrm{Pr}_{4}$ at room temperature. In addition, reducing the polymerization temperature may improve the controllability of $\mathrm{Ti}$ catalysts.

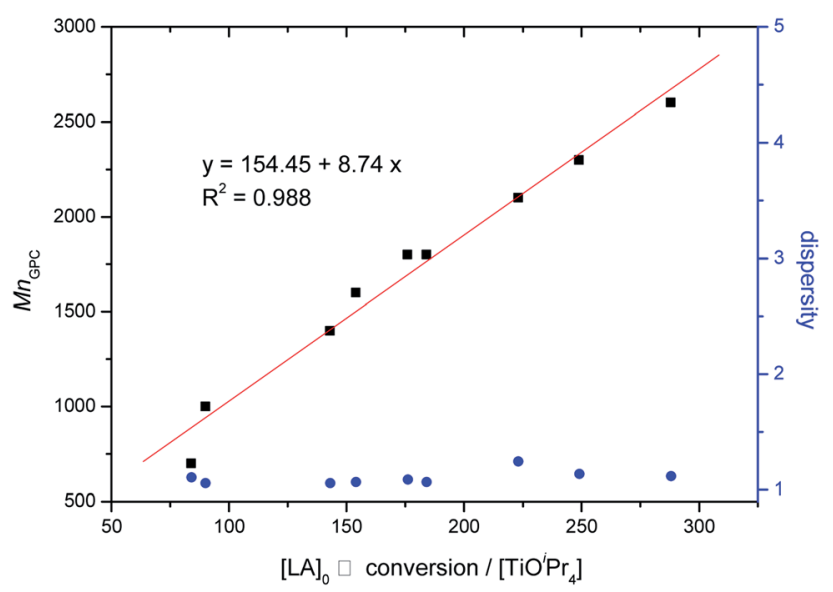

Fig. 4 Linear plots of $M_{\mathrm{n}_{\mathrm{PCC}}}$ versus ([LA] $\times$ conv.)/[TiO'Pr$\left.{ }_{4}\right]$. Blue solid dots indicate $Đ$ s.

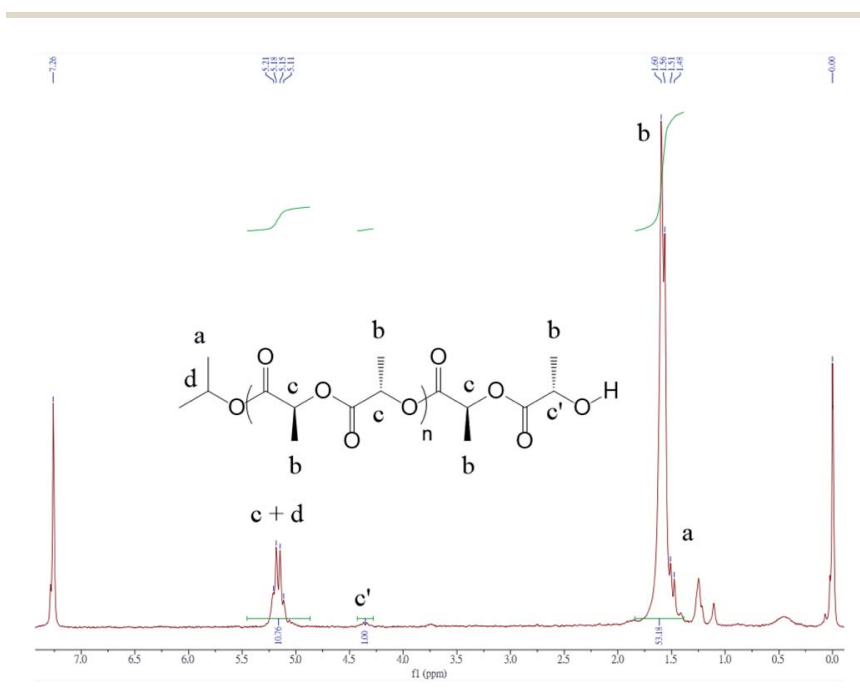

Fig. $5{ }^{1} \mathrm{H}$ NMR spectrum of PLA (entry 13 in Table 2).
All pyrazole derivatives improved the catalytic activity of TiO ${ }^{\mathrm{i}} \mathrm{Pr}_{4}$ in the following order: ${ }^{\mathrm{Bu}} \mathrm{Pz}>{ }^{\text {fur }} \mathrm{Pz}>{ }^{\mathrm{H}} \mathrm{Pz}>{ }^{\mathrm{Py}} \mathrm{Pz}>{ }^{\mathrm{Cl}} \mathrm{Pz}=$ ${ }^{\text {thio }} \mathrm{Pz}={ }^{\mathrm{MeO}} \mathrm{Pz}>{ }^{\mathrm{Ph}} \mathrm{Pz}>{ }^{\mathrm{Me}} \mathrm{Pz}>\mathrm{Tz}$ (Table 2). In the $\mathrm{CH}_{2} \mathrm{Cl}_{2}$ solution, the pyrazole ligand provided the benefit of considerable improvement of the catalytic reaction. For example, $k_{\mathrm{obs}}$ of $\mathrm{TiO}^{\mathrm{i}} \mathrm{Pr}_{4}$ with ${ }^{\mathrm{Bu}} \mathrm{Pz}$ was 17 times higher than that of $\mathrm{TiO}^{\mathrm{i}} \mathrm{Pr}_{4}$, and $k_{\text {obs }}$ of $\mathrm{TiO}^{\mathrm{i}} \mathrm{Pr}_{4}$ with ${ }^{\text {fur }} \mathrm{Pz}$ was 13 times higher than that of $\mathrm{TiO}^{\mathrm{i}} \mathrm{Pr}_{4}$. In addition, the controllability of $\mathrm{TiO}^{\mathrm{i}} \mathrm{Pr}_{4}$ with all pyrazole derivatives was improved $(\theta=1.07-1.12)$. Although $\mathrm{TiO}^{\mathrm{i}} \mathrm{Pr}_{4}$ with ${ }^{\mathrm{Bu}} \mathrm{Pz}$ revealed the highest polymerization rate, ${ }^{\mathrm{Bu}} \mathrm{Pz}$ is overly expensive. Therefore, ${ }^{\text {fur }} \mathrm{Pz}$ was used as a ligand with $\mathrm{TiO}^{\mathrm{i}} \mathrm{Pr}_{4}$ as a catalyst to polymerize LA with various ratios of [LA]/ [TiO $\left.{ }^{\mathrm{i}} \mathrm{Pr}_{4}\right]$ (entries 12-19, Table 2). The [LA]/[TiO $\left.{ }^{\mathrm{i}} \mathrm{Pr}_{4}\right]$ ratio from 37.5 to 62.5 was investigated, and the molecular mass $\left(M_{\mathrm{n}_{\mathrm{GPC}}}\right)$ of PLA increased from 1400 to 2100 . According to the solubility of LA in $\mathrm{CH}_{2} \mathrm{Cl}_{2}$, the limit of the [LA]/[TiO $\left.{ }^{\mathrm{i}} \mathrm{Pr}_{4}\right]$ ratio is 62.5 (1.80 g of LA in $2.5 \mathrm{~mL} \mathrm{CH}_{2} \mathrm{Cl}_{2}$ ), and PLA with high molecular mass PLA cannot be synthesized by increasing the $[\mathrm{LA}] /\left[\mathrm{TiO}^{\mathrm{i}} \mathrm{Pr}_{4}\right]$ ratio.

To investigate the living property ${ }^{68,69}$ of $\mathrm{TiO}^{\mathrm{i}} \mathrm{Pr}_{4}$ with the pyrazole ligand in LA polymerization, first, LA was polymerizated ([LA] : [ $\left.\mathrm{TiO}^{\mathrm{i}} \mathrm{Pr}_{4}\right]:\left[{ }^{\mathrm{fur}} \mathrm{Pz}\right]=100: 4: 4$ in $\mathrm{CDCl}_{3}$, entry 16 in Table 2). After $390 \mathrm{~min}$, the conversion was $84 \%$, and 100 equivalents of LA were reloaded into the solution (entry 17 in Table 2). However, the polymerization time increased to 895 min with a $92 \%$ conversion. Subsequently, 100 equivalents of LA were reloaded into the solution (entry 18 in Table 2), and the polymerization rate decreased. After $1495 \mathrm{~min}$, the conversion was $83 \%$, and 100 equivalents of LA were reloaded into the solution (entry 19 in Table 2). The solution could not be stirred after 2000 min with a $72 \%$ conversion. The slower LA polymerization rate can be ascribed to the higher viscosity of the polymerizated solution. On the basis of the linear relationship between $M_{\mathrm{n}_{\mathrm{GPC}}}$ and $\left([\mathrm{LA}]_{0} \times\right.$ conv. $) /\left[\mathrm{TiO}^{\mathrm{i}} \mathrm{Pr}_{4}\right]$ (entries 7, and 12-19 in Table 2 and Fig. 4), $\mathrm{TiO}^{\mathrm{i}} \mathrm{Pr}_{4}$ with the pyrazole ligand demonstrated a high controllability with narrow $Ð$ for LA polymerization. To confirm that PLA with high molecular mass can be synthesized using $\operatorname{TiO}^{\mathrm{i}} \mathrm{Pr}_{4}$ with the pyrazole ligand, LA was polymerizated using $\mathrm{TiO}^{\mathrm{i}} \mathrm{Pr}_{4}$ with ${ }^{\text {fur }} \mathrm{Pz}\left([\mathrm{LA}]:\left[\mathrm{TiO}^{\mathrm{i}} \mathrm{Pr}_{4}\right]:\left[{ }^{\text {fur }} \mathrm{Pz}\right]\right.$ $=1000: 1: 1$ at $100{ }^{\circ} \mathrm{C}$ without solvent, entry 20 in Table 2). After $240 \mathrm{~min}$, the conversion was $93 \%$, and PLA $\left(M_{\mathrm{n}_{\mathrm{GPC}}}=\right.$

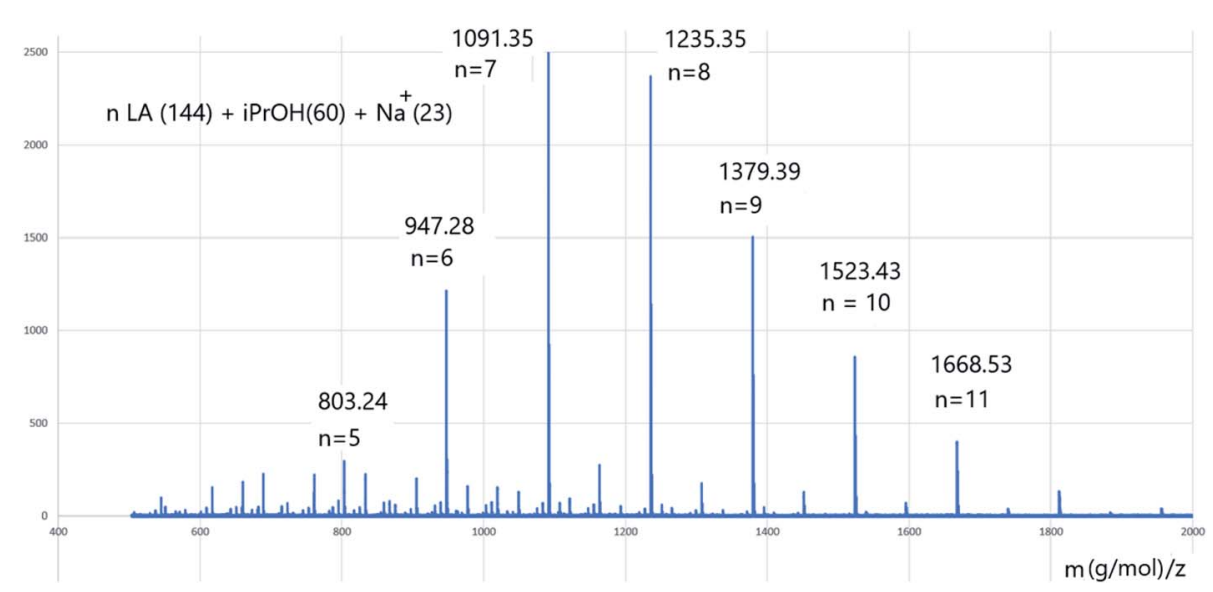

Fig. 6 MALDI-TOF spectrum of PLA (entry 13 in Table 2). 

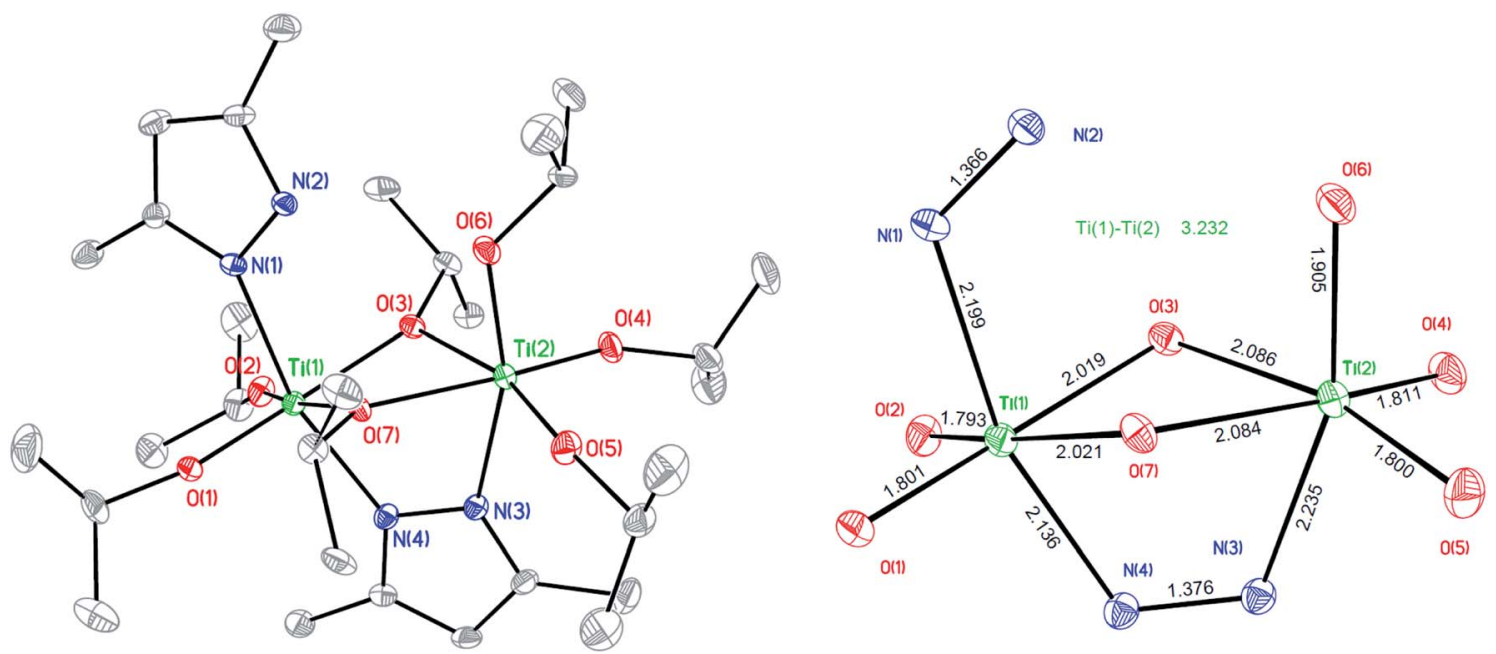

Fig. 7 Molecular plot of ${ }^{\mathrm{Me}} \mathrm{Pz}_{2} \mathrm{Ti}_{2} \mathrm{O} \mathrm{Pr}_{7}$ with $20 \%$ probability ellipsoids (all hydrogen atoms were omitted for clarity).

51 100, and $Ð=1.10$ ) was obtained. Compared with LA polymerization using $\mathrm{TiO}^{\mathrm{i}} \mathrm{Pr}_{4}$ without ${ }^{\text {fur }} \mathrm{Pz}(240 \mathrm{~min}$, conv. $=52 \%$, $M_{\mathrm{n}_{\mathrm{GPC}}}=31600, D=1.26$, entry 21 in Table 2 ), adding ${ }^{\text {fur }} \mathrm{Pz}$ to LA polymerization improved the polymerization rate and enhanced the controllability for producing PLA.

The ${ }^{1} \mathrm{H}$ nuclear magnetic resonance (NMR) spectrum of PLA (entry 2 in Table 2 and Fig. 5) confirmed the presence of one isopropyl oxide group (peak a) and a hydroxyl chain end (peak $\mathrm{c}^{\prime}$ ), suggesting that initiation occurred through insertion of an isopropyl oxide into LA. The matrix-assisted laser desorption/ ionization time-of-flight (MALDI-TOF) mass spectrum of PLA (entry 5 in Table 2 and Fig. 6) revealed the presence of isopropyl oxide group at the end of the PLA chain.

\subsection{Synthesis and characterization of ${ }^{{ }^{\mathrm{Me}}} \mathrm{Pz}_{2} \mathrm{Ti}_{2} \mathrm{O}^{\mathrm{i}} \mathrm{Pr}_{7}$}

To determine what was the real catalysis mechanism in the polymerization process, the reaction of ${ }^{\mathrm{Me}} \mathrm{Pz}$ and $\operatorname{TiO}^{\mathrm{i}} \mathrm{Pr}_{4}(1: 1)$ in toluene was investigated. Fig. 7 illustrates the crystal of ${ }^{\mathrm{Me}} \mathbf{P z}_{2} \mathbf{T i}_{2} \mathbf{O}^{\mathbf{i}} \mathbf{P r}_{7}$ (CCDC 1568213, Table S4 $\dagger$ ). However, the ${ }^{1} \mathrm{H}$ NMR spectrum (Fig. S3 $\dagger$ ) revealed that ${ }^{{ }^{\mathbf{e}}} \mathbf{P z}_{2} \mathbf{T i}_{2} \mathbf{O}^{\mathbf{i}} \mathbf{P r}_{7}$ was impure. The crystal data of ${ }^{\mathbf{M e}} \mathbf{P z}_{2} \mathbf{T i}_{2} \mathbf{O}^{\mathbf{i}} \mathbf{P r}_{7}$ indicated that the TiTi distance was 3.2322(14) A, which is slightly shorter than that of $\mathbf{L}^{\mathbf{B u}}$-TiOPr $_{\mathbf{6}}{ }^{38}$ distance (3.242 $\AA$ ), and it implied the cooperative activation can occur in this system. To prove that ${ }^{\mathbf{M e}} \mathbf{P z}_{2} \mathbf{T i}_{2} \mathbf{O}^{\mathbf{i}} \mathbf{P r}_{7}$ is the real catalyst in LA polymerization, the crystal of impure ${ }^{\mathbf{M e}} \mathbf{P z}_{\mathbf{2}} \mathbf{T i}_{\mathbf{2}} \mathbf{O}^{\mathbf{i}} \mathbf{P r}_{7}$ was used as a catalyst in LA polymerization with the polymerization condition of entry 17 of Table 1 ([LA]: $\left[{ }^{\mathbf{M e}} \mathbf{P z}_{2} \mathbf{T i}_{2} \mathbf{O}^{\mathbf{i}} \mathbf{P r}_{7}\right]=100: 0.5,\left[{ }^{\mathbf{M e}}{ }^{\mathbf{P z}} \mathbf{T}_{2} \mathbf{T i}_{2} \mathbf{O}^{\mathbf{i}} \mathbf{P r}_{7}\right]=6.7 \mathrm{mM}$ at $60{ }^{\circ} \mathrm{C}$ in $15 \mathrm{~mL}$ toluene). After $16 \mathrm{~min}$, the conversion was 95\% with $M_{\mathrm{n}_{\mathrm{GPC}}}=4900, Ð=1.56$, and $k_{\mathrm{obs}}=0.203\left(\mathrm{~min}^{-1}\right)$, and the results were similar to the results of entry 17 of Table 1 (conversion was $89 \%$ after $25 \mathrm{~min}$ ).

\section{Conclusions}

Our strategy of using $\mathrm{TiO}^{\mathrm{i}} \mathrm{Pr}_{4}$ with pyrazole ligand for one-pot LA polymerization successfully improved the catalytic activity compared with using $\mathrm{TiO}^{\mathrm{i}} \mathrm{Pr}_{4}$ only. The crystal structure of ${ }^{\mathbf{M e}} \mathbf{P z}_{\mathbf{2}} \mathbf{T i}_{\mathbf{2}} \mathbf{O}^{\mathbf{i}} \mathbf{P r}_{\mathbf{7}}$ revealed cooperative activation between two $\mathrm{Ti}$ atoms during LA polymerization. These results can provide a straightforward approach to synthesize PLA by using $\mathrm{TiO}^{\mathrm{i}} \mathrm{Pr}_{4}$ as a catalyst. In future, we intend to investigate the mechanism of LA polymerization.

\section{Conflicts of interest}

There are no conflicts to declare.

\section{Acknowledgements}

This study was supported by the Ministry of Science and Technology of Taiwan (Grant MOST 108-2113-M-037-017) and Kaohsiung Medical University (NSYSUKMU 107-P010 and KMUDK109004). We thank the Centre for Research Resources and Development at Kaohsiung Medical University for instrumentation and equipment support.

\section{Notes and references}

1 Y. Mato, T. Osobe, H. Takada, H. Kanehiro, C. Ohtake and T. Kaminuma, Environ. Sci. Technol., 2001, 35, 318-324.

2 D. S. Green, B. Boots, D. J. Blockley, C. Rocha and R. Thompson, Environ. Sci. Technol., 2015, 49, 5380-5389.

3 J. R. Jambeck, R. Geyer, C. Wilcox, T. R. Sieglar, M. Perryman, A. Andrady, R. Narayan and K. L. Law, Science, 2015, 347, 768-771.

4 J. Lamb, B. L. Willis, E. A. Foiorenza, C. S. Couch, R. Howard, D. N. Rader, J. D. True, L. A. Kelly, A. Ahmad, J. Jompa and C. D. Harvell, Science, 2018, 359, 460-462.

5 A. P. Gupta and V. Kumar, Eur. Polym. J., 2007, 43, 40534074.

6 M. Skotak, A. P. Leonov, G. Larsen, S. Noriega and A. Subramanian, Biomacromolecules, 2008, 9, 1902-1908. 
7 Y. Zhu, C. Romain and C. K. Williams, Nature, 2016, 540, 354-362.

8 N. Kamaly, B. Yameen, J. Wu and O. C. Farokhzad, Chem. Rev., 2016, 116, 2602-2663.

9 K. Liu, X. Jiang and P. Hunziker, Nanoscale, 2016, 8, 1609116156.

10 C. G. Palivan, R. Goers, A. Najer, X. Zhang, A. Car and W. Meier, Chem. Soc. Rev., 2016, 45, 377-411.

11 J. Y. Park, G. Gao, J. Jang and D.-W. Cho, J. Mater. Chem. B, 2016, 4, 7521-7539.

12 S. K. Shukla, S. K. Shukla, P. P. Govender and N. G. Giri, RSC Adv., 2016, 6, 94325-94351.

13 A. U. Birnin-Yauri, N. A. Ibrahim, N. Zainuddin, K. Abdan, Y. Y. Then and B. W. Chieng, Polymers, 2017, 9, 165.

14 S. Medel, Z. Syrova, L. Kovacik, J. Hrdy, M. Hornacek, E. Jager, M. Hruby, R. Lund, D. Cmarko, P. Stepanek, I. Raska and B. Nyström, Eur. Polym. J., 2017, 93, 116-131.

15 A. Watts, N. Kurokawa and M. A. Hillmyer, Biomacromolecules, 2017, 18, 1845-1854.

16 C. Xiang and N. C. Acevedo, Polymers, 2017, 9, 179.

17 S. Bhowmick, A. V. Thanusha, A. Kumar, D. Scharnweber, S. Rother and V. Koul, RSC Adv., 2018, 8, 16420-16432.

18 B. Slater, S. O. Wong, A. Duckworth, A. J. P. White, M. R. Hill and B. P. Ladewig, Chem. Commun., 2019, 55, 7319-7322.

19 M. A. Woodruff and D. W. Hutmacher, Prog. Polym. Sci., 2010, 35, 1217-1256.

20 Y. Ramot, M. Haim-Zada, A. J. Domb and A. Nyska, Adv. Drug Delivery Rev., 2016, 107, 153-162.

21 F. Carosio, S. Colonna, A. Fina, G. Rydzek, J. Hemmerlé, L. Jierry, P. Schaaf and F. Boulmedais, Chem. Mater., 2014, 26, 5459-5466.

22 B. H. Huang, C. Y. Tsai, C. T. Chen and B. T. Ko, Dalton Trans., 2016, 45, 17557-17580.

23 C. Redshaw, Dalton Trans., 2016, 45, 9018-9030.

24 Y. Wei, S. Wang and S. Zhou, Dalton Trans., 2016, 45, 44714485.

25 Y. A. Chang and R. M. Waymouth, J. Polym. Sci., Part A: Polym. Chem., 2017, 55, 2892-2902.

26 T. Fuoco and D. Pappalardo, Catalysts, 2017, 7, 64.

27 K. M. Osten and P. Mehrkhodavandi, Acc. Chem. Res., 2017, 50, 2861-2869.

28 C. Redshaw, Catalysts, 2017, 7, 165.

29 R. Ligny, M. M. Hanninen, S. M. Guillaume and J. F. Carpentier, Chem. Commun., 2018, 54, 8024-8031.

30 E. Stirling, Y. Champouret and M. Visseaux, Polym. Chem., 2018, 9, 2517-2531.

31 A. B. Kremer and P. Mehrkhodavandi, Coord. Chem. Rev., 2019, 380, 35-57.

32 M. Chen and C. Chen, Chin. J. Chem., 2020, 38, 282-286.

33 O. Santoro and C. Redshaw, Catalysts, 2020, 10, 210.

34 Z. Sun, Y. Zhao, O. Santoro, M. R. J. Elsegood, E. V. Bedwell, K. Zahra, A. Walton and C. Redshaw, Catal. Sci. Technol., 2020, 10, 1619-1639.

35 T. K. Saha, M. Mandal, D. Chakraborty and V. Ramkumar, New J. Chem., 2013, 37, 949.

36 J.-X. He, Y.-L. Duan, X. Kou, Y.-Z. Zhang, W. Wang, Y. Yang and Y. Huang, Inorg. Chem. Commun., 2015, 61, 144-148.
37 D. Mandal, D. Chakraborty, V. Ramkumar and D. K. Chand, RSC Adv., 2016, 6, 21706-21718.

38 H. C. Tseng, H. Y. Chen, Y. T. Huang, W. Y. Lu, Y. L. Chang, M. Y. Chiang, Y. C. Lai and H. Y. Chen, Inorg. Chem., 2016, 55, 1642-1650.

39 C. B. Durr and C. K. Williams, Inorg. Chem., 2018, 57, 1424014248.

40 L. A. Brown, J. L. Rhinehart and B. K. Long, ACS Catal., 2015, 5, 6057-6060.

41 B. Gao, X. Li, R. Duan and X. Pang, New J. Chem., 2015, 39, 2404-2408.

42 R. Duan, Z. Qu, X. Pang, Y. Zhang, Z. Sun, H. Zhang, X. Bian and X. Chen, Chin. J. Chem., 2017, 35, 640-644.

43 S. H. Kim, J. Lee, D. J. Kim, J. H. Moon, S. Yoon, H. J. Oh, Y. Do, Y. S. Ko, J.-H. Yim and Y. Kim, J. Organomet. Chem., 2009, 694, 3409-3417.

44 A. L. Zelikoff, J. Kopilov, I. Goldberg, G. W. Coates and M. Kol, Chem. Commun., 2009, 6804.

45 C. Romain, L. Brelot, S. p. Bellemin-Laponnaz and S. Dagorne, Organometallics, 2010, 29, 1191-1198.

46 H.-W. Ou, H.-Y. Chen, H.-C. Tseng, M.-W. Hsiao, Y.-L. Chang, N.-Y. Jheng, Y.-C. Lai, T.-Y. Shih, Y.-T. Lin and H.-Y. Chen, J. Mol. Catal. A: Chem., 2014, 394, 97-104.

47 R. R. Gowda, D. Chakraborty and V. Ramkumar, Eur. J. Inorg. Chem., 2009, 2981-2993.

48 H. Y. Chen, M. Y. Liu, A. K. Sutar and C. C. Lin, Inorg. Chem., 2010, 49, 665-674.

49 R. R. Gowda, D. Chakraborty and V. Ramkumar, Inorg. Chem. Commun., 2011, 14, 1777-1782.

50 M. T. Jiang, S. R. Kosuru, Y. H. Lee, W. Y. Lu, J. K. Vandavasi, Y. C. Lai, M. Y. Chiang and H. Y. Chen, eXPRESS Polym. Lett., 2018, 12, 126-135.

51 S. L. Hancock, M. F. Mahon and M. D. Jones, Dalton Trans., 2011, 40, 2033-2037.

52 L. C. Liang, S. T. Lin and C. C. Chien, Inorg. Chem., 2013, 52, 1780-1786.

53 M. Jeong Go, J. Min Lee, K. Mun Lee, C. Hwa Oh, K. H. Park, S. H. Kim, M. Kim, H.-R. Park, M. H. Park, Y. Kim and J. Lee, Polyhedron, 2014, 67, 286-294.

54 D.-C. Liu, C.-Y. Li, P.-H. Lin, J.-D. Chen, C.-Y. Tsai, C.-H. Lin and B.-T. Ko, Inorg. Chem. Commun., 2018, 90, 1-7.

55 C.-Y. Li, C.-J. Yu and B.-T. Ko, Organometallics, 2012, 32, 172180.

56 L. C. Liang, Y. L. Hsu and S. T. Lin, Inorg. Chem., 2011, 50, 3363-3372.

57 M. Y. Lowe, S. Shu, S. M. Quan and P. L. Diaconescu, Inorg. Chem. Front., 2017, 4, 1798-1805.

58 X. Xu, G. Luo, Z. Hou, P. L. Diaconescu and Y. Luo, Inorg. Chem. Front., 2020, 7, 961-971.

59 R. L. Webster, N. Noroozi, S. G. Hatzikiriakos, J. A. Thomson and L. L. Schafer, Chem. Commun., 2013, 49, 57-59.

60 D. J. Gilmour, R. L. Webster, M. R. Perry and L. L. Schafer, Dalton Trans., 2015, 44, 12411-12419.

61 J. Liu, Y. Cao, L. Li, H. Pei, Y. Chen, J. Hu, Y. Qin, Y. Li, W. Li and W. Liu, RSC Adv., 2015, 5, 10318-10325.

62 Y. Kim, G. K. Jnaneshwara and J. G. Verkade, Inorg. Chem., 2003, 42, 1437-1447. 
63 C. J. Chuck, M. G. Davidson, M. D. Jones, G. Kociok-köhn, M. D. Lunn and S. Wu, Inorg. Chem., 2006, 45, 6595-6597.

64 J.-B. Zeng, M. Srinivansan, Y.-D. Li, R. Narayan and Y.-Z. Wang, J. Polym. Sci., Part A: Polym. Chem., 2010, 48, 5885-5890.

65 A. G. Amador, A. Watts, A. E. Neitzel and M. A. Hillmyer, Macromolecules, 2019, 52, 2371-2383.

66 F. Malbosc, V. Chauby, C. S.-L. Berre, M. Etienne, J.-C. Daran and P. Kalck, Eur. J. Inorg. Chem., 2001, 2689.
67 Y. Yu, E. J. Fischer, G. Storti and M. Morbidelli, Ind. Eng. Chem. Res., 2014, 53, 7333-7342.

68 O. Dechy-Cabaret, B. Martin-Vaca and D. Bourissou, Chem. Rev., 2004, 104, 6147-6176.

69 N. E. Kamber, W. Jeong, R. M. Waymouth, R. C. Pratt, B. G. G. Lohmeijer and J. L. Hedrick, Chem. Rev., 2007, 107, 5813-5840. 